\title{
O Erro Judiciário de Araguari na Literatura
}

\author{
Eliene Rodrigues de Oliveira1
}

RESUMO: O presente artigo parte de uma pesquisa em andamento, pretende tecer breves apontamentos sobre a história dos dois irmãos que, em plena ditadura Vargas, foram torturados por um tenente para confessarem um crime que nunca existiu. Reconhecidamente intitulada de O Caso dos Irmãos Naves, a história foi registrada em livro e serviu de fonte inspiradora para a criação de outros trabalhos artísticos.

PALAVRAS-CHAVE: O Caso dos Irmãos Naves; Violência; Direito; Literatura.

ABSTRACT: The present article comes from a research in development. It intends to make brief notes about the history of two brothers who, during Vargas' dictatorship, were tortured by a lieutenant in order to confess a crime that never existed. Recognizedly entitled The case of the Brothers Naves, the history was registered in a book and was an inspiring source for the creation of other artistic works.

KEY-WORDS: Thecase of the Brothers Naves; Violence; Law; Literature.

Este estudo é um aprofundamento de uma investigação sobre a interseção entre o Direito e o Teatro, iniciada em 2005, junto ao I Curso de Especialização em Interpretação Teatral pela Universidade Federal de Uberlândia-MG, sob orientação do professor Dr. Luiz Humberto Martins Arantes. A pesquisa ora iniciada estuda o processo de construção de um texto teatral, a partir dos autos processuais, tendo como referência O Caso dos Irmãos Naves, clássico erro jurídico brasileiro.

Desde os tempos antigos, os trabalhos artísticos trazem como temática questões jurídicas, como é o caso das tragédias gregas, sendo "Antígona", de Sófocles, um exemplo clássico. No teatro brasileiro, muitos dramaturgos utilizaram-se da escrita para criticar/denunciar a realidade jurídica, tal qual

${ }^{1}$ Mestranda em Artes pelo Programa de Pós-Graduação em Artes do Instituto de Artes da Universidade Federal de Uberlândia-MG. Linha de Pesquisa: Fundamentos e Reflexões em Artes/Teatro. Orientador: Prof. Dr. Luiz Humberto Martins Arantes. Bolsista CAPES. 
Martins Pena, em "O Juiz de Paz na Roça", e Plínio Marcos, em "Barrela". Pensando nas tantas possibilidades e trabalhos já realizados, a escolha de trabalhar O Caso dos Irmãos Naves se deve também pelo fato de que o ocorrido foi codificado em vários suportes artísticos. Rastros de memória de um tempo e um lugar.

\section{O Caso}

Na década de 1930, em Araguari-MG, os irmãos Sebastião e Joaquim Naves trabalhavam com afinco na compra e revenda de cereais e outros artigos agrícolas². De caminhão, percorriam a região de "Nova Ponte (antigamente Ponte Nova), Irai, Monte Carmelo, Abadia dos Dourados, Cascalho Rico, Indianópolis, Grupiara e Estrela do Sul" para adquirirem a mercadoria destinada para Araguari e Uberlândia (ALAMY FILHO, 1960, p.15).

Esperançosos com a prosperidade do trabalho, Joaquim fez sociedade com o seu primo e hóspede Benedito Pereira Caetano, para a compra, à prestação ${ }^{3}$, de um caminhão Ford V-8, novo, retirado na agência local. "O caminhão, como lançadeira de tear, (que) vai e vem, incansável noite e dia" permitiu a rápida liquidez da dívida. (ALAMY FILHO, 1960, p.15)

Porque o trabalho se solidificava, Benedito aventurou-se num negócio de risco maior que os anteriores. Tomou dinheiro emprestado com a família e adquiriu (a prazo) mais de duzentas sacas de arroz, que ficaram depositadas num armazém de Araguari, à espera de vendê-las no momento em que os preços estivessem em alta. Circunstância contrária, os preços não paravam de despencar. A mercadoria desvalorizou e, com receio de que a espera gerasse maior prejuízo, Benedito vendeu a safra de arroz. Noventa contos de réis, a melhor oferta por ele encontrada. Mas, prejuízo contabilizado, o dinheiro recebido não cobriria o valor para pagar o arroz (compra a prazo no valor de

\footnotetext{
2 "Arame farpado, sal, querosene, ferramenta rudimentar de lavoura." (ALAMY FILHO, 1960, p. 1)

3 Pelo valor de 16:000\$000.
} 
cento e trinta e seis contos de réis), tampouco para assumir a dívida com a família.

No dia 26 de novembro de 1937, sexta-feira, Benedito contou do prejuízo aos primos, que o advertiram a agir com prudência e não descontar o cheque antes da segunda-feira, dada a movimentação das festividades que aconteceriam naquele final de semana na cidade. Na manhã do dia seguinte, porém, Benedito foi ao banco e sacou o dinheiro. A sua inquietação e ansiedade foram percebidas pelos seus primos, que também estavam preocupados com a situação.

No domingo, dia 28, os irmãos e o primo participaram da inauguração de uma ponte na cidade. Contrariando novamente o conselho dos primos, Benedito levou consigo, sob a roupa, o dinheiro. "Não satisfeito com as festividades da manhã, à noite compareceu às "barraquinhas" do parque de exposições. Na madrugada do dia 29, ele desapareceu." (SOUSA, 1996, p.21). Desaparecimento que culminou, inicialmente, num grande mistério e depois, num grande drama que afetou muitas vidas.

“[...] Diante do desaparecimento de Benedito, os irmãos Joaquim Naves Rosa (25 anos) e Sebastião José Naves (32 anos) saíram à sua procura por toda a cidade. Passaram por todos os lugares aonde pensavam que ele poderia estar. Toda a cidade foi vasculhada, inclusive a casa da "horizontal Floriza", com a qual o desaparecido passava algumas noites. Não encontrando Benedito, os Irmãos Naves resolveram procurar a polícia. Ao delegado civil, Ismael do Nascimento, declararam que Benedito estava endividado e que os noventa contos de réis eram insuficientes para pagar os credores. Diante das declarações de Sebastião e Joaquim Naves e dos pais de Benedito, o delegado instaurou um inquérito policial. Alguns dias se passaram. Algumas pessoas foram ouvidas. Entre elas, José Lemos da Silva (proprietário do Armazém Lemos), Sebastião Vieira da Costa (amigo de Benedito), Floriza Martins da Silva e João Batista Ferreira (um dos últimos a ver Benedito). $\mathrm{O}$ delegado não conseguiu solucionar o caso que se espalhava rapidamente pela cidade. A 
população, não contente com o andamento das investigações, clamou por um delegado militar que esclarecesse o desaparecimento de Benedito. No dia 22 de dezembro de 1937, os araguarinos foram atendidos e o cargo de delegado passou a ser ocupado pelo Tenente Francisco Vieira dos Santos. Frente à inquietação dos habitantes de Araguari, o novo delegado precisou encontrar solução para o caso." (SOUSA, 1996, p.22)

Depois de pensar, investigar, ouvir o burburinho da cidade e perguntar, o delegado abriu, às vésperas da passagem de ano, no dia 29 de dezembro, novo inquérito policial e mandou intimar José Prontidão ${ }^{4}$, Orcalino Tubém ${ }^{5}$ e os irmãos Sebastião e Joaquim Naves para prestarem depoimento. Logo na primeira "conversa" dos dois irmãos com o delegado, este já os mandou prender.

Nesse sentido, é interessante pensar no papel estratégico da prisão.

“[...] A prisão adapta-se ao novo espírito do século XX: é no tempo que o homem produz o mundo capitalista e se produz como membro da sociedade capitalista e é no controle sobre o tempo do infrator que um condenado é punido. Em outras palavras, a máxima popular "tempo é dinheiro" encontraria seu correspondente no sistema punitivo como "a retirada do tempo é punição". Além disso, na prisão, o controle absoluto das horas - de acordar, de comer, do banho, de dormir - torna-se a disciplina por excelência; o controle panóptico é total. A apresentação da prisão - lugar em que não só o infrator é depositado, longe dos olhos dos homens de bem, mas no qual ele tem todos os seus passos vigiados - é, então, a moderna forma civilizada das penas, a ocupar o lugar do suplício." (BRITO, 2008, p.23)

Nos exatos trinta dias após o desaparecimento de Benedito, José Prontidão foi levado de Uberlândia a Araguari e, em seu depoimento, informou

4

José Joaquim Theodoro de Lima. Orcalino da Costa e Silva. 
“ [...] ter conhecido um Benedito Pereira em Uberlândia, o qual procurava carona em direção à Uberaba ou São Paulo. Após suas declarações, Tte. Vieira mandou prendê-lo. A segunda testemunha foi Ana Rosa Naves, sexagenária de Joaquim e Sebastião Naves. Ela era sogra de José Prontidão e assim o levou para depor." (SOUSA, 1996, p.22)

Por ser permitido ao Prontidão prestar depoimento em Uberlândia, perante o delegado de lá, com remessa do depoimento para Araguari, “começava errado o novo delegado" (ALAMY FILHO, 1960, p.40), ademais, o Tenente ignorou as importantes declarações de Prontidão, que sinalizaram o sumiço de Benedito e não a sua morte. Prontidão dissera que as descrições físicas do homem com quem ele trabalhara recentemente em Uberlândia indicavam o mesmo suposto Benedito "assassinado" e que esse saíra de viagem com um caminhoneiro, na condição de ajudante, até Itumbiara, com destino para Mato Grosso. Versão esta que fez com que o delegado intimasse Ana Naves.

Ambos os depoimentos, que eram verdadeiros e compatíveis, geraram efeito contrário por parte do Tenente. Em vez de ele seguir as pistas e averiguar quem seria esse homem que trabalhou com Prontidão, preferiu alimentar a vaga hipótese de que essa versão fora criada para acobertar o suposto crime cometido pelos filhos de Donana e entendê-la como uma pista de que os Naves cometeram o latrocínio. Ideia reforçada “depois do depoimento de Orcalino Tubém, que colocava Sebastião e Joaquim Naves como culpados pelo desaparecimento de Benedito." (SOUSA, 1966, p.34)

A mente do tenente já trabalhava mais propensa para a segunda pista, talvez por ser mais simples, prática, menos trabalhosa e de imediata verificação (ALAMY FILHO, 1960, p.43). Permanecem presos os irmãos desde a posse do novo delegado que iniciara a sua criativa invenção ardilosa. Mandou prender 
Prontidão que, violentado fisicamente ${ }^{6}$, rendeu-se aos mandos do delegado e disse que Joaquim Naves pediu-lhe que

“[...] fizesse um depoimento na polícia, alegando que Benedito Pereira havia passado em Uberlândia, dando deste os sinais característicos já declarados em fls. destes autos, dizendo mais ao depoente que ele Joaquim e seus irmãos estavam em apuros aqui, por causa do desaparecimento de Benedito; que para esse serviço Joaquim prometeu dar ao depoente uma gratificação não dizendo porém a importância da mesma; que a seu ver a responsável pelo desaparecimento de Benedito Pereira é Joaquim Naves Rosa, pelos motivos que acima já expôs; que a primeira vez que Joaquim procurou o depoente não estava acompanhado e da conversa que ambos tiveram ninguém mais participou; que, na segunda vez que Joaquim Naves foi a Uberlândia, estava acompanhado de um tio de Benedito (o desaparecido), por nome Pedro Pereira da Silva, para assim melhor se disfarçar; que à vista do pedido formulado por Joaquim o depoente disse ao tio de Benedito, Pedro Pereira, que o mesmo Benedito havia estado em Uberlândia, dando destes os sinais, os quais coincidiram com os do desaparecido, ficando Pedro Pereira julgando que de fato Benedito por ali passara, quando não era verdade; que, meditando depois no ato que praticara, resolveu, para um desencargo de consciência, dizer a verdade do que havia à autoridade, sobre o desaparecimento de Benedito Pereira; que, ao ver do depoente, o responsável pelo dito desaparecimento é o Joaquim Naves Rosa, a julgar pela proposta que o mesmo lhe fizera; que o Joaquim Naves não disse ao depoente para que fim era o seu

6 “A tortura, segundo o psicanalista Hélio Pellegrino, busca “à custa do sofrimento corporal insuportável, introduzir a cunha que leve à cisão entre o corpo e a mente." A tortura, que foi sistematicamente utilizada pelos governos autoritários, mesmo durante todo o século XX e que não dá sinais de ter sido superada, está intimamente relacionada com o suplicio. A diferença parece ser a de que este tem uma carga semântica que o relaciona apenas com o corpo físico, infligindo sempre dor física." (BRITO, 2008, p.25) 
depoimento a prestar nesta delegacia." (ALAMY FILHO, 1960, p.47$48)^{7}$

Assim, no dia 03 de janeiro de 1938, foi forjada a primeira acusação de peso contra dos Irmãos. Tortura bem sucedida, continuaram as pressões físicas e morais para simular novos dados acusatórios. Presas para depor, as esposas de Joaquim e Sebastião (Antônia Rita de Jesus e Salvina Olina de Jesus, respectivamente) não se intimidaram com as pressões do delegado e foram soltas. Ato contínuo, ele mandou prender a Donana, senhora com sessenta anos de idade. Agredida das mais variadas formas (físicas e morais) na frente (e junto) dos próprios filhos, ela não sucumbiu. Sustentou a sua verdade. Não acusou os filhos, tampouco pediu/permitiu que eles confessassem o crime para livrarem-na daquele martírio. Permaneceram "firmes" filhos e mãe. Cada qual violentado e "esmagado" aos olhos dos outros.

Libertada, Donana procurou o advogado João Alamy Filho que, fazendo coro à voz do povo e ao seu clamor por "justiça em prol do desaparecimento de Benedito", era contra os Irmãos Naves, porque o pouco já ouvido a respeito era o bastante para ele acreditar no crime. Também, o delegado anunciava a coleta de provas, faltando apenas a confissão. Dessa feita,

“[...] Desculpando-se, recusou participar da defesa. Crime bárbaro. Latrocínio. Sem justificativa. Sem defesa. Impossível estar do lado deles, quem lastimava a vítima. Era natural que a mãe, acreditasse no que lhe diziam os filhos. Mesmo que eles não fossem culpados, ela os defenderia. Não, Donana. Não é possível. Nunca defendemos criminosos de crimes dessa natureza. É natural o seu sofrimento e nós respeitamos a sua dor. Mas não podemos forçar a nossa linha de conduta profissional. Queira desculpar-nos. Há outros. Procure-os. Não faltará defesa a seus filhos. Procure as autoridades e peça para soltá-los. Mas nada podemos fazer por eles." (ALAMY FILHO, 1960, p.53)

$7 \quad$ Trecho dos autos processuais (Fls. 20/22 verso - Polícia de Minas Gerais. PRIMEIRA TESTEMUNHA (reinquirida) constante na obra de Alamy. 
Dois dias depois da recusa por parte do advogado, a mãe dos Naves voltou a procurá-lo acompanhada de um fazendeiro amigo - Aleixo Resende -, que se propôs a pagar os honorários advocatícios. Alamy manteve a recusa e expôs ao fazendeiro além dos motivos ditos à Donana, que não tinha interesse no caso por uma questão de ética profissional que o fazia acreditar na experiência do militar e que, portanto, o caso estava bem conduzido e os seus princípios e convicções não eram corrompidos por dinheiro. ${ }^{8}$

Ana Rosa foi presa novamente por muitos dias. No porão da delegacia, ela

“[...] foi vítima de surra, bofetões, socos, chutes. Tte. Viera a prendeu com a intenção de, ao ver seus filhos espancados ou viceversa, obter a confissão tão almejada. Não medindo seus atos, ele espancou os Irmãos Naves na presença da "velhinha". Não surtindo efeito, os amarrou nus de frente à sua mãe, a qual se encontrava na mesma situação. Deixou-os assim por uma semana com sede e fome. Todavia, diante da inflexível postura da família Naves, o delegado, em um ato de extrema irracionalidade e violência, estuprou D. Ana com requintes de crueldade. Em seguida, a submeteu a novo ato de violência sexual. Desta vez, praticado por seus próprios subordinados." (SOUSA, 1996, p.23-24)

Amparados pela coragem materna, os irmãos apanharam, resistiram e não se dispuseram à esperada "confissão". Infrutífera mais uma tentativa violenta por parte do delegado. Ana Rosa foi solta. Dirigiu-se à casa de Alamy, não mais pela sua condição de advogado, mas guiada apenas pelo instinto da busca de proteção.

8 Essa passagem revela a influência do discurso do Tenente na comunidade. Para Sousa (1996, p.23), "Deve-se salientar que, enquanto agia no interior da delegacia, o delegado também exerceu um pode de persuasão e coerção sobre a população, conseguindo colocar a opinião pública contra os irmãos Naves." 
"[...] Vai, quase inconsciente, rua afora. Buscando o quê? Se não há esperança. Se não há caridade. Para onde ir? Vai e vai. Chega e entra. Timidamente, como corça espingardeada. Vara a casa. É a terceira vez que entra ali, que passa por aquela porta. Já não quer mais o advogado. Mais nada, senão matar a fome, mitigar a sede, fugir à polícia. Esconder-se. Pela misericórdia de Deus, suplica a caridade do cristão. Desfigurada. Transfigurada. Impressionante. Comovida, chorando, comove a gente da casa. Marido e mulher. Somos tomados de intensa piedade. Acolhemo-la, sob promessa de proteção à pessoa. Ficasse quieta. Escondida. Não se mostrasse à janela. A ninguém. Ficaria ali. Era mãe. Sua dor santificava-a. Era uma dor de mãe, desvelada em carinho pelos filhos martirizados. Sofria por eles, sofria com eles. Ficou. Um, dois, cinco dias. Eternidade na sua dor. Tinha muita coisa que contar. Contou. Ouvimo-la emocionados. Nossa esposa chorava. Também era mãe. Heloísa, pequenina e vivaz, graciosa e feliz, compunha a nossa felicidade, e remarcava o sentimento materno de uma esposa exemplar. Tornou-se subitamente amiga de Donana. Recolhia o carinho transbordante da mãe duramente castigada pela malvadez e pela inconsciência humana. Em seus braços, mitigava a angústia daquela sertaneja, cuja bondade se lhe adivinhava nos olhos castanhos, longínquos. Saudosos do passado. Heloísa nos seus braços. Lágrimas nos olhos dela e nos de Odete, mãe de Heloísa. Só Heloísa não tinha lágrimas. Insensível ao drama que vivia a sua improvisada pajem. A vovozinha emprestada. Porque era inocente. Inocente. Inocente!" (ALAMY FILHO, 1960, p. 52-53)

Enternecido com Donana e convencido da inocência dos dois jovens, que, ante os tormentos todos mantiveram a honra, Alamy resolve atuar na causa e entrar com pedido de habeas-corpus para que os irmãos respondessem em liberdade a acusação.

“[...] Era 6 de janeiro de 38. A coisa estava do mesmo feitio. Não adiantava a violência. Nada. Eles estavam irredutíveis. De nossa parte, entregamos os pontos. Rendido à razão, às súplicas de Ana 
Rosa, não tínhamos alternativa. Era entrar duro na luta. Então, o remédio legal gritava: Habeas-corpus! A prisão ilegal durava dias. Embora clandestina, era sabida de todos. Não tínhamos juiz togado na comarca. Era o de Paz, investido. Honesto. Correto. Mas, sem tirocínio. Sem conhecimento algum. Sem capacidade ou competência. Tinha de ser o de Uberlândia. Sereno. Íntegro. Grande. Sabíamos. Conhecíamos, todos. Fomos lá. Levamos o pedido." (ALAMY FILHO, 1960, p.53-54)

No período de análise do pedido de soltura, o tenente aumentava sua impaciência pela "não-confissão" e sua criatividade para arquitetar eficazes atrocidades que atingissem o alvo - a "confissão". Por muitos dias, os irmãos foram conduzidos até um mato distante e "deserto". Lá, tendo forte sol ou chuva, apanhavam nus, amarrados (ou não) em árvores com cabeças para baixo e untados de mel para atrair insetos, formigas, marimbondos, mosquitos, abelhas. Durante vários dias, as cenas se repetiram até que, no dia 12 de janeiro de 1938, na beira do Rio Araguari, amarrados em árvores diferentes e distantes, para um irmão ficar invisível ao outro, o tenente disse que iria matá-los. Atirou próximo aos ouvidos de Sebastião. Ele gritou, mas resistiu. Joaquim que a tudo ouviu e ainda acreditou quando o Tenente disse que seu irmão estava morto e que, se ele não confessasse o crime, morreria também, aceitou a condição de "confessar". "Por piedade, seu tenente! Não me mate! Eu faço o que o senhor quiser! Pode escrever. Assino tudo, não me mate! Não aguento mais." (ALAMY FILHO, 1960, p.57-58)

Assim, Joaquim confessou uma "história" criada pelo Tenente, assumindo para si e para o irmão a culpa. Também se submeteu a protagonizar a reconstituição do crime, chegando ao ponto de cavar buracos com as mãos em busca dos noventa contos de réis. Não bastassem tais agressões físicas e psíquicas, chegando à delegacia, sofreu mais espancamentos e acabou declarando que o dinheiro estava aos cuidados de Inhozinho, seu cunhado. Este foi procurado pelo delegado. Com esses depoimentos todos, restou aos irmãos Naves a condição de principais suspeitos do crime. 
Em 13 de janeiro de 1938, foi concedida a liberdade de Sebastião e Joaquim Naves em atenção ao pedido de habeas-corpus. Mas o tenente trapaceiro retirou os irmãos da cadeia e os conduziu para lugar ermo. Mentiu ao juiz que os irmãos já haviam sido soltos.

No dia 15 de janeiro era apresentada denúncia contra os irmãos, por parte do promotor, o que cessaria a intervenção do delegado ${ }^{9}$. Mas não! O delegado instaurou outro inquérito, em paralelo ao processo judiciário, "para assegurar-se de que as testemunhas, atropeladas, coatas e submissas, repetissem em juízo o que quisessem a polícia. Assim foi até o fim. Ilegal e criminosamente tolerado pelas autoridades civis locais." (ALAMY FILHO, 1960, p.75-80)

Ameaçada de estupro, Antônia Rita acusou o Joaquim (seu marido) e o cunhado de terem cometido o assassinato e sua sogra de ter escondido o dinheiro. Em 17 de janeiro de 1938, foi decretada prisão preventiva de Joaquim Naves, que prestou depoimento acusando sua mãe de receptadora do dinheiro roubado. Salvina foi detida com seus filhos ${ }^{10}$. Por conta dos maus tratos, o seu filho Wilsinho, de dez meses, faleceu. Ana Rosa, acusada de ser cúmplice teve sua prisão decretada ${ }^{11}$ e foi detida em 09 de fevereiro de 1938. Novos depoimentos ocorreram por parte de Salvina, Joaquim e Sebastião. (SOUSA, 1996, p.28-36)

Várias outras irregularidades somaram-se aos fatos citados. Esgotadas e em vão foram todas as alternativas por parte do advogado para que as fraudes policiais fossem desmascaradas e a família inocentada e liberta. Houve quatro julgamentos. No primeiro e segundo, os irmãos foram absolvidos, mas a

\footnotetext{
9 De acordo com a legalidade o delegado só poderia executar diligência expressamente determinada pelo juiz.

10 Trecho da decisão da anulação do processo: "Salvina, [...] afirma: 'Esteve presa dois dias, porque se recusara a dizer que seu marido, à noite havia estava fora de casa'. O depoimento de Salvina, é, de fato, um tremendo libelo contra a crueza e os processos de violência inaudita do então Tte. delegado especial do Município de Araguari. Revela Salvina que: 'Depois disso, estando a depoente privada de qualquer alimentação e passando frio, em companhia de um filho menor (criança esta a quem amamentava, e que morreu em condições assaz duvidosa, ut atestado de óbito, fls.), e ainda ameaçada de ser despida e espancada, confessou o que lhe impuseram na polícia'." (ALAMY FILHO, 1960, p.360)

$11 \quad$ Em 05 de fevereiro de 1938.
} 
Promotoria recorreu e o terceiro julgamento, em 4 de julho de 1939, condenouos a vinte e cinco anos e seis meses de reclusão. Alamy entrou com pedido de revisão criminal e, em 14 de agosto de 1940, a pena foi reduzida para dezesseis anos e seis meses de prisão celular.

“[...] Devido ao bom comportamento de Sebastião e Joaquim Naves, o Juiz de Direito de Araguari - Dr. Fernando Bhering, aceitou o pedido de livramento condicional assim como sugerido, unanimemente, pelo Conselho Penitenciário do Estado de Minas Gerais. Em 12 de agosto de 1946, os irmãos Naves ganharam liberdade condicional após terem cumprido mais da metade da pena que lhes foi imputada." (SOUSA, 1996, p. 43)

Dezesseis meses após a liberdade condicional, Joaquim Naves faleceu $^{12}$. Pobre e doente num asilo de Araguari. Nove meses depois, foi a partida do Tenente Vieira ${ }^{13}$. Sebastião, apesar de todas as agruras, manteve-se alerta procurando pistas do suposto morto, o que durou até 24 de julho de 1952, quando a falsa vítima foi descoberta (sob ajuda de Sebastião) e presa pela polícia na fazenda dos seus pais, em Nova Ponte. (ALAMY FILHO, 1960, p.343)

“[...] Benedito Pereira Caetano, a suposta vítima, não podendo conter por mais tempo o desejo de rever seus familiares, retorna sub-repticiamente ao lar paterno, dissimulando o seu aspecto físico pelo crescimento de longa barba e de bigode, anteriormente não usados por ele, em traje diverso do seu habitual. No dia 24 de julho de 1952, nesse retorno, encontra acidentalmente, num cruzamento rodoviário, com um seu antigo colega de escola primária, que o reconhece e o procura. Ele, todavia, esquiva-se, dizendo àquele de seu engano confundindo-o com outrem. Furta-se ao reconhecimento e apressa, prevenido, seu regresso à fazenda dos pais. Não se deu enganado o colega, que era também um membro da 
família Naves, primo dos injustiçados. Imediatamente telegrafou a Sebastião Naves, em Araguari, comunicando-lhe o encontro e afirmando que Benedito estava na fazenda de seus pais. De posse do telegrama, Sebastião, ajudado pelo repórter local do Diário de Minas, Felício De Lucia Neto, solicita à polícia uma escolta, para prevenir reação, e parte em busca do "morto"." (ALAMY FILHO, 1960, p.364365)

O ressuscitado teve prisão preventiva decretada em 25 de julho de 1952. O advogado Alamy, que estava em Belo Horizonte, a serviço, foi comunicado e socializou a notícia com o diretor do Diário de Minas, que "fretou um avião e voou para Araguari, acompanhado de outros repórteres e fotógrafos, realizando uma das maiores reportagens do Brasil." (ALAMY FILHO, 1960, p.365).

Durante o tempo em que ficou detido, a comunidade araguarina se dirigia à cadeia para vê-lo. Apelidaram-no de "animal exótico e raro", o suposto morto. Mas esse fenômeno durou até 04 de agosto do mesmo ano, quando sua prisão foi revogada pela falta de motivos e pelo sensacionalismo em torno do seu aparecimento.

“[...] um erro não justifica o outro. Se os Irmãos Naves foram vítimas de um inqualificável erro judiciário, não se deve estender esse erro, de conseqüências desastrosas, à pessoa de Benedito Pereira Caetano, que hoje aparece esclarecendo um 'crime que não houve' e explicando, satisfatoriamente, que ignorava tudo o que se passara na sua ausência. [...] Não há, até agora, prova alguma de que tenha o preso furtado ou se apropriado de qualquer coisa, de alguém. O dinheiro que estaria em seu poder, na época de seu desaparecimento, foi-lhe emprestado. Ele é apenas devedor de uma quantia, a parentes seus, de que nada queixam [...] Mesmo admitindo-se, para argumentar, que tivesse havido apropriação indébita, já teria ocorrido a prescrição." (ALAMY FILHO, 1960, p.349-350) 
Em 14 de outubro de 1953, sentença judicial declarou a inexistência do crime ${ }^{14}$; a absolvição de Sebastião e Joaquim Naves e a responsabilidade do Estado a indenizar os injustiçados pelos prejuízos sofridos. ${ }^{15}$

“[...] a reparação pecuniária jamais poderá ressarcir as famílias dos injustiçados do que elas perderam e deixaram de ser, em decorrência de seu estado, postas em indigência durante tantos anos, pela infamante acusação de latrocínio pensando sobre seus chefes. Mas isto é o que a Justiça oferece como reparação." (ALAMY FILHO, 1960, p.387-388)

Em maio de 1958, o título de “A Mãe Brasileira do Ano" foi concedido à Ana Naves Rosa, que foi presenteada com um colar de pérolas e uma casa. Em junho de 1963, um mês depois da morte de seu filho Sebastião Naves, ela faleceu ${ }^{16}$.

14 Trecho dos autos processuais: "Sob o número 1 632/952, distribuída a revisão a insigne juiz, Dês. José Maria Burnier Pessoa de Mello, para relatá-la, culminou com a anulação do processo criminal contra os irmãos Naves, por acórdão unânime dos ilustres desembargadores de Minas Gerais, em Câmaras Criminais Reunidas, em 14 de outubro de 1953. Decisão memorável, em que o "próprio tribunal, reformando-se a si mesmo, ensina e prega, pela técnica e pelo exemplo, a juventude do Direito e a eterna realeza da Justiça', no dizer do eminente relator, em seu voto imortal. Essa histórica decisão, pela sua elevação moral e estupenda coragem cívica, pela primeira e quiçá única vez no Brasil, reconheceu e determinou fosse aplicada a norma do artigo 630, do Código de Processo Penal, em face do pedido formulado por nós na revisão, para que se reconhecesse aos injustiçados direito a uma justa indenização a ser paga pelo Estado. O voto, minucioso e brilhante, proferido pelo Juiz Burnier, foi unanimente subscrito pelos seus pares. Dele, o teor que segue. [...] E o Estado pagará aos réus, injustamente condenados, uma justa indenização pelos prejuízos sofridos. A injustiça da condenação ressaltada pela ressurreição do 'morto' imaginário, decorreu, na espécie, principalmente, de não haver o acórdão condenatório se estribado em corpo de delito qualquer, direto ou indireto, para reconhecer o verdadeiro assassínio de Benedito com o escopo de furto. E também de se haver como livre uma confissão manifestamente extorquida pela violência policial, confissão que, assim, impede a imunização do Estado." (ALAMY FILHO, 1960, p.353-354)

15 No entanto houve vários recursos e, só em 08 de janeiro de 1960, que o Supremo Tribunal Federal julgou ser o Estado de Minas o responsável pela indenização. (Acórdão - fls. 568: 8-1-1960 - Maria Orminda - Tribunal Pleno RECURSO EXTRAORDINÁRIO N. 42-723 - Minas Gerais)

16 Antônia Rita de Jesus faleceu em maio de 1961 e Sebastião Naves em maio de 1963. "Dentre os membros da família Naves que sofreram mais diretamente a intimidação da polícia estado-novista, Salina Olina de Jesus (esposa de Joaquim Naves) foi a última a morrer)." (SOUSA, 1996, p.48). 
O Caso dos Naves teve repercussão nacional e internacional. Permaneceu no imaginário coletivo e, ainda hoje, "meio" século depois do seu "fim", é considerado como um dos maiores exemplos de erros da Justiça brasileira. Assim,

“[...] o aparato policial de Getúlio Vargas, comandado em Araguari por Tenente Vieira dos Santos, conseguiu manipular a opinião pública fazendo com que esta passasse a desconfiar de toda a família Naves e a elogiar as atitudes da autoridade policial. Através de métodos coercitivos a polícia estado-novista foi a grande responsável pela condenação de Sebastião e Joaquim Naves, principalmente, com a intimidação das testemunhas e informantes conseguidas após sessões de torturas, espancamentos e seviciamentos." (SOUSA, 1996, p.06)

Essa passagem do texto "O Caso dos Irmãos Naves": o poder coercitivo da farda, escrito pelo historiador Marcos Souza, permite uma reflexão para além de enxergar o Tenente Vieira como o vilão e único responsável pela citada tragédia. Foi ele apenas mais uma peça comandada pelo "quebra-cabeças de fardas" da época.

\section{O Caso na Literatura}

Reconhecidamente intitulada de O Caso dos Irmãos Naves, a história foi a fonte inspiradora para a criação de diversos trabalhos artísticos e culturais, alguns dos quais de mesmo nome, quais sejam: o livro "O Caso dos Irmãos Naves - o erro judiciário de Araguari", de João Alamy Filho (1960); o filme "O Caso dos Irmãos Naves", dirigido por Luís Sérgio Person e co-roteirizado por Jean-Claude Bernardet (1967); a música "Erro Judiciário", de Sulino e Dr. Antônio Carlos (1994), regravada por Leyde \& Laura com o nome de "O Caso Irmãos Naves" (2002); o episódio televisivo exibido no Programa Linha Direta 
Justiça - TV Globo (2003) ${ }^{17}$, sob direção de Pedro Vasconcellos ${ }^{18}$; o espetáculo teatral "O Caso dos Irmãos Naves" do Grupo EmCena dirigido por Thiago Scalia (2006)19, e a “Visita Técnica O Caso dos Irmãos Naves - a história de um erro", turismo pedagógico-cultural idealizado pela historiadora Viviane Lemes (2012).

O livro de Alamy é um relato do acontecido para esclarecer a verdade dos fatos e tentar contribuir para a melhor aplicação da lei. Um misto de literatura com transcrições dos autos processuais, ${ }^{20}$ que serviu de inspiração para a redação do roteiro do filme concebido para denunciar a ditadura militar e a violência.

No texto “Direito \& Literatura. Anatomia de um desencanto: desilusão jurídica em Monteiro Lobato", Arnaldo Godoy (2003) apresenta um estudo de obras literárias e autores (com formação jurídica) e declara que é possível conhecer o Direito a partir da Arte. Dentre as conclusões por ele apresentadas, a de que a "Literatura avalia o Direito" e "os textos literários demonstram desencanto com o Direito" permite-nos uma analogia aos escritos de Alamy, cuja narrativa por si só denuncia as mazelas do Judiciário ${ }^{21}$.

No último capítulo do livro - "Anulação do Processo" -, Alamy redige o texto "Diatribes à nossa atuação", para mostrar ao leitor que, reconhecido o Erro e apesar de todo o seu esforço para que justiça fosse feita, ele foi alvo de ataques por parte de "grandes doutos da lei", que disseram que aos irmãos faltou defesa eficiente. Em entrevista concedida ao Jornal A Noite, do Rio de Janeiro, ${ }^{22}$ intitulada de 'SINTO HORROR PELA INOCÊNCIA MARTIRIZADA',

\footnotetext{
17 Exibição em 18 de dezembro - o último episódio de Linha direta justiça em 2003. Lançado no youtube em maio de 2010. Disponível em $<$ http://www.youtube.com/watch?v=_MliUKSDVSM>. Acesso em: 18 set. 2011.

18 A montagem demandou quatro meses de produção e traz no elenco Emilio Orciollo Neto, Bruce Gomlevski, Jackson Antunes, Aracy Balabanian, Leon Góes, Aramis Trindade, Alexia Garcia e Érica Lustosa. Apresenta depoimentos dos atores Juca de Oliveira, Raul Cortez e John Herbert, que participaram do filme. Este dado serve de indício de que o filme serviu de inspiração para a montagem do episódio.

19 O espetáculo foi concebido em 2006 e retomou temporada em 2009, 2010 e 2011.

20 Informações constantes na apresentação do livro "O Caso dos Irmãos Naves: o erro judiciário de Araguari"

$21 \quad$ Num recorte de tempo.

22 Entrevista também publicada no Diário de Minas de 03 de agosto de 1952.
} 
o Professor Roberto Lira - na época, presidente da Sociedade Brasileira de Criminologia - referiu-se a Alamy como sendo um advogado sem imaginação e cabedal, ao comentar:

“[...] Não quero contribuir para outro 'erro judiciário', cedendo a uma paixão bela e útil que nem por isso deixa de perturbar e desorientar. Sinto, como homem e como cidadão, o mesmo horror pela inocência martirizada. Mas, ao julgar, já agora, o delegado, o promotor, o juiz acusador, procuro conter-me pela própria lição do erro. E, como 'a corda arrebenta pelo lado mais fraco', temo que tudo, afinal, venha a recair sobre as costas estreitas de um policial modesto e rude. [...] Não sei se o advogado esgotou a farmácia para evitar ou corrigir o erro com o afã do atual pedido da indenização. [...] É claro que não se justifica a inércia da magistratura e do Ministério Público, mas, psicologicamente, um dos fatores da indiferença é a alegação sistemática de violências policiais pela defesa. Degrada-se assim a grave imputação reduzida a lugar comum de advogados sem imaginação e sem cabedal." (ALAMY FILHO, 1960, p.368-370)

Em resposta, Alamy publicou uma crônica jornalística no Diário de Minas argumentando preferir acreditar que tal feito não tivesse a pretensão de ferir

“[...] a dignidade profissional do obscuro advogado da roça [...] A defesa, na precariedade de meios e garantias, fez o que the foi possível. Quem já advogou no interior poderá avaliar o que representa ter em contrário a opinião pública inteiramente desvairada. Não fizemos só isso, expusemos a nossa própria segurança, sem visar qualquer compensação de ordem material e exclusivamente por espírito de caridade. Não ficamos nas 'alegações sistemáticas de violências policiais' porque, felizmente, em nosso linguajar rude e destituído de retórica sempre dissemos o necessário e o possível em defesa de nossos constituintes. [...] se a nossa pobre 'farmácia' não nos pode fornecer as drogas preciosas dos eruditos, nem por isso deixamos de usar das ervas do campo, que sempre 
temos à mão, sem o afã do atual pedido de indenização, que será sempre mesquinho ante a magnitude dos danos causados aos acusados e ás suas famílias, uma das quais perdeu seu chefe ainda infamado pela pecha de ladrão. A possibilidade dessa compensação escapou à nossa perspicácia tanto como à argúcia dos juízes." (ALAMY FILHO, 1960, p.371-372)

Essa parte do livro mostra o desencanto de Alamy em relação à retórica, ao excesso de discurso, à influência (negativa) do clamor público nas decisões e à larga distância entre os "Julgadores" e os jurisdicionados. Demonstra desilusão em relação à falta de aplicabilidade da lei, a hierarquia (e segregação de funções) dentro do próprio Poder Judiciário. Denota, também, um incômodo para com a irreparabilidade dos danos morais.

Nessa óptica, para Godoy (2003), a literatura, ao enfocar épocas e instituições, consegue captar o jurídico como produto cultural. Muito embora essa sua fala refira-se a estudos de obras literárias ficcionais e não à "literatura como narrativa de memória", é possível extrair desse pensamento a considerável importância que teve e tem o registro literário de Alamy. A sua narrativa serviu de fato gerador para muitos outros trabalhos artísticos que levaram (e levam) ao público pontos de vista sobre um relevante recorte histórico da realidade brasileira. É uma ilustração de personagens feita pela recordação de um dos protagonistas que, depois de findos os mais 'importantes' capítulos dessa história, articulou a imprensa, levou ao prelo a narrativa, trouxe formato artístico e, portanto, voz para um fato que, ainda hoje, desperta a atenção. E esse despertar, pressupõe-se, é devido à qualidade da sua escrita. Ora, "o escritor, por causa de sua origem e experiência de vida, evidencia o mundo em que vive, sua experiência é o substrato de um tempo; o escritor faz a crônica da humanidade." (GODOY, 2003, p.29)

Essa crônica da humanidade é que denuncia uma desumanidade na época da ditadura Vargas e que é feita por meio de lembranças de quem a viveu, dialoga com o pensamento de Ignácio de Loyola Brandão. Em entrevista concedida às pesquisadoras Márcia Regina Naxara e Vera Lúcia Silva Vieira 
sobre "literatura, história e memória" (2010), ele ensina que

“[...] a literatura, buscando a memória, buscando as lembranças e retratando o cotidiano, acaba fornecendo os elementos de que se precisa e que são necessários para entender como é que as coisas vieram a acontecer. E a literatura, sendo verdade, não vai permitir que no futuro esse momento seja distorcido. Porque se um dia os militares escreverem a história, eles vão escrever do ponto de vista deles; mas o ponto de vista deles é um e o ponto de vista de quem viveu aqui é outro." (NAXARA; VIEIRA; 2010, p.215)

Segundo as pesquisadoras, nas declarações de Loyola, chamou a atenção o desejo de memória.

“[...] Para ele, no período ditatorial surgiu uma literatura que "sendo feita com arte, tinha, no entanto uma influência forte do jornalismo, do documentário, do depoimento, com os acontecimentos cotidianos se refletindo sobre a produção. Claro que alguns fizeram melhor, outros pior. O que marcava, no entanto, era o desejo sincero de retratar os fatos, antes que se perdessem. Evitar que escoassem para o esgoto da história, fornecendo um álibi ao sistema duro e desumano que imperava sobre o Brasil. O ato da escrita desponta como "dor e sofrimento", mas, sobretudo, como "indignação", como modo de "lutar, desabafar, resistir, informar ao futuro o que estava se passando", sentir-se participante. Procurar vencer a frustração de ver "as coisas acontecerem" e não poder contar." (NAXARA; VIEIRA; 2010, p.208-209)

Esse desejo de retratar os fatos, de desabafar e informar ao futuro é claramente descrito pelo advogado de Araguari. Os seus relatos demonstram solidariedade para com a "dor e sofrimento" alheios e "indignação", sendo ele participante dos fatos. O curioso é que os seus textos, o seu estilo de escrita, permitem ao leitor sentir-se participante do ocorrido. Permitem ao leitor se 
reportar àquele passado e compartilhar daquela dor e sofrimento a ponto de, ao fechar o livro, parar e refletir sobre as agruras do seu tempo.

Loyola, ainda citado por Márcia e Vera (2010) observa que,

“[...] nas lacunas e lacunas da história, o que conta é a memória, imenso baú do tempo; nele coexistem passado, presente e futuro, temporalidades distintas que se digladiam, sem deixarem de solidarizar. Toda literatura, no fundo, é política: na medida em que você fala do homem, das condições em que o homem vive, ela vira uma literatura política. [...] Literatura que constrói memória; disputas simbólicas que fundam para a posteridade percepções e visões de mundo, valores, sensibilidades e desejos; lança ao futuro um legado de seu presente (momento da escrita) e do passado (reminiscências como matéria-prima para a escrita no presente). Arte, como arma literária apontada para a ditadura, vista como a "inimiga a se combater", mas também como a faculdade que "provoca prazer e encantamento" a partir das histórias contadas." (NAXARA; VIEIRA; 2010, p.209-210)

O extrato dessa fala nos possibilita pensar no grande legado deixado pelos rastros de Alamy. A sua publicação é um produto cultural cuja urdidura tão fortemente construída amarrou fios de memórias que se transformaram em fonte inspiradora para criações artísticas. O seu trabalho, de cunho jurídico, ultrapassou a linguagem técnico-jurídica e avançou para outras "fronteiras do saber", atingindo novos públicos e não ficando restrito apenas ao âmbito jurídico. Isso é grandioso. E, para além das criações artísticas, comprova-se quando percebemos que no próprio Direito, quando fazem referência ao Erro, não ficam presos aos autos processuais, recorrem os professores aos trabalhos artísticos, notadamente ao filme, como veremos adiante. Interessante notar a importância da escrita para a "geração" desses novos trabalhos. Filme, episódio televisivo e teatro se reportaram à literatura, e isso fica claro quando, ao assistir a eles, percebemo-nos de volta às lembranças (às imagens) de partes do livro. 
Os escritos de Alamy enquadram-se à categoria do "direito na literatura". A maior parte dos estudos sobre Direito \& Literatura aponta obras ficcionais. Muitas delas, redigidas por advogados ${ }^{23}$. No texto “O Direito \& Literatura"24, Godoy (2008) elucida que não é por acaso que os textos literários abordam questões jurídicas.

“[...] Wigmore inquietava-se no sentido de precisar onde escritores encontrariam material jurídico para os enredos que desenvolviam. Muitos escritores eram formados em Direito, ou então viveram experiências pessoais desagradáveis e marcantes, do ponto de vista jurídico. Tomando-se como referencial a literatura brasileira, menciono as Memórias do Cárcere, de Graciliano Ramos, como indicativo de experiência pessoal amarga. Acrescento Monteiro Lobato, e toda sua literatura para adultos, especialmente a revelada nos contos que escreveu, que denunciam profundo mal estar para com a prática jurídica." (GODOY, 2008, p.32)

23 "A chamada ocupação principal do escritor influencia a obra, imprimindo à mesma o contingencial e o episódico do artista. É uma opinião sincera que busca-se. Rápido bosquejo na Literatura Brasileira sedimenta a opinião. [...] Boa parte de nossos escritores era de bacharéis em Direito, e muitos deles exerceram a advocacia, a promotoria ou a magistratura. Nomeadamente: Gregório de Matos Guerra, Cláudio Manoel da Costa, Tomás Antonio Gonzaga, Gonçalves Dias, Álvares de Azevedo, Castro Alves, José de Alencar, Raul Pompéia, Raimundo Correia, Alphonsus de Guimaraens, Augusto dos Anjos, Graça Aranha, Godofredo Rangel, Oswald de Andrade, Alcântara Machado, José Lins do Rego, Clarice Lispector, Jorge Amado, Lygia Fagundes Telles e Monteiro Lobato." (GODOY, 2003, p.27)

24 "Há reconhecimento oficial das relações entre Literatura e Direito, o que ficou comprovado com o provão de avaliação do MEC, aplicado em junho de 1999, enquanto redigia a pesquisa. No provão de Direito, questão n.22, os examinadores, a partir de um texto de Júlio Ribeiro, começaram: "A literatura sempre foi rica de comentários, alusões e observações penetrantes em relação ao direito e às leis." Os comentários da Folha de São Paulo, edição de 14 de junho de 1999, reconheceram que "A pergunta foi eminentemente filosófica e comparativa." (GODOY, 2003, p.155) 
Nesse aspecto, talvez, o grande diferencial do trabalho de Alamy seja o fato de não somente enquadrar-se na citada categoria, mas não ser ficcional. Vale também reconhecer que a sua escrita é tão rica (traz ritmo, poesia, leveza) que propicia ao leitor a sensação da leitura de uma ficção ${ }^{25}$. trata de um ponto de vista e que as memórias são maleáveis. 


\section{REFERÊNCIAS BIBLIOGRÁFICAS:}

ALAMY FILHO, João. O Caso dos Irmãos Naves: O erro judiciário de Araguari. São Paulo: Círculo do Livro. 390 p.

BARROSO, Inezita. Inezita Barroso. Cantora e Apresentadora de TV. São Paulo, jun. 2010. Entrevista concedida ao programa Produção Cultural no Brasil. Disponível em $\quad<\underline{\text { http://www.producaocultural.org.br/wp- }}$ content/themes/prod-cultural/integra/integra-inezita-barroso.html $>$. Acesso em: 16 abr. 2012.

BERNADET, Jean-Claude; PERSON, Luis Sérgio. O Caso dos Irmãos Naves: chifre em cabeça de cavalo. Roteiro Original comentado por Jean Claude Bernardet. São Paulo: Imprensa Oficial do Estado de São Paulo: Cultura - Fundação Padre Anchieta, 2004. 216 p.

BRITO, Manoel de. Quando a fiçãa se confunde com a realidade As obras In der Strafkolonie/Na Colônia Penal e Der Process/O Processo de Kafka como filtros perceptivos da ditadura civil-militar brasileira. São Paulo: Série: Produção Acadêmica Premiada. Faculdade de Filosofia, Letras e Ciências Humanas. USP. 2008. $228 \quad$ p. $\quad$ Disponível em < http://www.spap.fflch.usp.br/sites/spap.fflch.usp.br/files/DLM_EDUARDO INTEGRAL.PDF>. Acesso em: 29 jan. 2012.

GODOY, Arnaldo Sampaio de Moraes. O Direito na Literatura. In: Direito $\mathcal{E}$ Literatura. Ensaio de Síntese Teórica. Porto Alegre: Livraria do Advogado, 2008, p. $27-58$.

. Direito \& Literatura. Anatomia de um desencanto: desilusão jurídica em Monteiro Lobato. Curitiba: Juruá, 2003. 180p.

LEMES, Viviane. O Caso dos Irmãos Naves. Disponível em $<$ http://flanarturismo.com.br/index.php/roteiros/caso-dos-irmaos-naves/> . Acesso em: 19 abr. 2012.

LINHA DIRETA. O Caso dos Irmãos Naves. Rio de Janeiro: TV Globo, dezembro de 2003. Programa de TV. 
MELODIA, Sidney. Sulino. Erro Judiciário. Caso dos Irmãos Naves. Música. Disponível em <http://www.youtube.com/watch?v=E0kjkOeDKxE>. Acesso em: 23 mar. 2012

NAXARA, Márcia Regina; VIEIRA, Vera Lúcia Silva. Entre a literatura, a história e a memória: entrevista com Ignácio de Loyola Brandão. ArtCultura, Uberlândia, v.13, n.22, p 207-224. jan.-jul. 2011. Disponível em: <http://www.artcultura.inhis.ufu.br/PDF22/vieira_naxara.pdf >. Acesso em: 04 fev. 2012

O CASO DOS IRMÃOS NAVES. Direção de Luis Sergio Person, roteiro de Jean Claude Bernardet, Brasil, 1967, DVD (92 min.), preto e branco.

O CASO DOS IRMÃOS NAVES. Direção: Thiago Scalia. Espetáculo Teatral, Brasil, 2011.

PERIPATO, Sandra Cristina. Discografia de Leyde e Laura. Recanto Caipira. Disponível em <http://www.recantocaipira.com.br/leyde_laura_discografia.html>. Acesso em: 23 mar. 2012

SIQUEIRA, Ada Bogliolo Piancastelli. Notas sobre Direito e Literatura: o absurdo do Direito em Albert Camus. vol. IV. Florianópolis: Ed. Da UFSC/Fundação Boitexu, 2011. Disponível em: <http://funjab.ufsc.br/wp/wpcontent/uploads/2012/02/Notas_sobre_direito_V_IV_texto.pdf >. Acesso em: 19 mar. 2012.

SOUSA, Marcos Paulo de. O Caso dos Irmãos Naves: o poder coercitivo da farda. 1996. Monografia (Graduação em História) - Universidade Federal de Uberlândia, Uberlândia, 1996. Or.: Christina da Silva Roquette Lopreato. 